\title{
AS GEO-GRAFIAS DA MEMÓRIA: O LUGAR FESTIVO COMO BIOGRAFIA ESPACIAL
}

\section{The geo-graphies of the memory: the festive place as a spatial biography}

\author{
Patrício Pereira Alves de Sousa ${ }^{1}$
}

\begin{abstract}
RESUMO
O presente texto analisa a constituição espaço-temporal de um festejo do Congado mineiro a partir dos rituais da Festa de Nossa Senhora do Rosário. A investigação se baseia na noção de "lugar festivo" como uma instituição discursiva que, através das narrativas performatizadas pelos rituais do Congado, define uma maneira de se conceber a história de vida de um lugar. A memória festiva é analisada como fruto de uma disputa de sentidos que negocia e elege as narrativas válidas sobre a biografia de um espaço, permitindo a construção de geo-grafias memoriais.
\end{abstract}

Palavras-chave: Espaço; memória; lugar festivo; Congado.

\begin{abstract}
This paper analyzes the spatial-temporal constitution of a Congado celebration in Minas Gerais from the rituals of the Our Lady of the Rosary. The research is based on the notion of "festive place" as a discursive institution that, through the narratives performed in Congado rituals, defines a way of conceiving the life history of a place. The festive memory is analyzed as the result of a dispute of senses that deals and elects valid narratives about the biography of a space, which leads to the construction of memorials geo-graphies.
\end{abstract}

Keywords: Space; memory; festive place; Congado. 


\section{CONVITE À FESTA}

Este é um texto sobre memórias, mas pode também ser tomado como uma memória sobre textos. Explico. É um esforço de registrar memórias, mas é também uma memória sobre inscrições e escritas. Trata-se de um exercício de sistematizar os encontros entre histórias de vida de sujeitos sociais com a biografia de um espaço. De dizer sobre a constituição de um lugar a partir das vidas que o animam e que por ele são animadas.

É um texto sobre memórias, enquanto análise de eventos memoriais que se inscrevem espacialmente. Uma memória sobre textos, enquanto relato de uma experiência de pesquisa e delineamento das escritas que a oralidade e o movimento dos corpos imprimem ao espaço. É, pois, um texto de Geografia sobre escritas e inscrições espaciais; sobre geo-grafias.

Hifenizar uma palavra de tão ampla utilização como geografia expõe este trabalho ao risco de ser acusado de imponderação. Entretanto, embora não seja esta uma palavra composta, em termos gramaticais, as semânticas do termo permitem-nos jogar com seus significados: em sua grafia, em seus usos, no deslocamento de seus sentidos e em suas distintas transcrições, traduções e inscrições. Assim, sugiro que o termo geografia, quando tomado para designar as escritas e inscrições espaciais, abre-nos uma série de possibilidades para problematizar as configurações espaciais emergidas no ato humano de organizar seus lugares.

O que busco neste texto é, pedindo licença aos guardiões da memória ${ }^{2}$ da Irmandade de Negros de Nossa Senhora do Rosário de São José do Triunfo (Viçosa, MG), transformar-me numa espécie de narrador capaz de relatar as memórias que me confiaram no desenrolar desta pesquisa. A análise que aqui apresento partiu do esforço de buscar compreender como a Festa de Nossa Senhora do Rosário, realizada no distrito em questão, cumpre a função de manter na memória do grupo social dela participante o processo de constituição do espaço e tempo social daquele lugar.

Vale salientar que pela opção do texto narrativo sou levado a utilizar, por vezes, do pronome em primeira pessoa, já que busco descrever uma experiência investigativa. Deixo claro, entretanto, que embora a narrativa seja minha, as ideias contidas no texto são resultado de inúmeros diálogos e debates realizados junto a colegas, grupo de pesquisa, autores consultados e sujeitos informantes. "Convite à festa" é, portanto, uma metáfora que utilizo aqui para jogar com a linguagem e tornar inteligível o caráter dialógico construtor desta investigação. Embora escrita individual, jamais texto solitário. Um texto formalmente monográfico no sentido stricto, mas uma poligrafia numa significação lato.

Este convite age, pois, em dois sentidos: um primeiro no sentido de apresentação da realidade e dinâmica da Irmandade de Negros de Nossa Senhora do Rosário em suas espacialidades em São José do Triunfo, e um segundo em convite ao conhecimento do relato de uma experiência de pesquisa realizada junto às memórias festivas geo-grafadas em São José do Triunfo por congadeiros. Convite realizado, acendamos os candeeiros.

\section{ACENDENDO CANDEEIROS}

Os corpos negros, como sugere Martins (1997), matizam territórios com seus movimentos e em suas oralituras $^{3}$, que como estiletes inscrevem a história e a cultura dos povos africanos em terras brasileiras. $O$ Congado, manifestação da religiosidade afro-brasileira, territorializa a corporeidade negra ao festejar suas memórias, cria lugares ao consagrar espaços. Nesse movimento, a memória permite a espacialidade ao construir lugares a partir das sociabilidades e das tensões entre aqueles que lembram. $\mathrm{O}$ espaço permite a memória à medida que as lembranças necessitam se apoiar em sua extensão para perdurar. As Geo-grafias da Memória são, pois, as espacializações e as espacialidades das memórias, neste caso, festivas.

A iniciativa desta investigação se fez pela constatação de nuances que a cidade de Viçosa, localizada na mesorregião da Zona da Mata Mineira, possui na forma de ocupação de seu território, no que se refere aos indicadores da população de idosos e negros, mostrando particularidades quando comparados os indicadores

2 Neste trabalho a expressão é utiliza a partir do entendimento de Von Simson (2008) do termo. Para a autora, os guardiões da memória representam um grupo que cumpre o papel social de transmitir às novas gerações a memória dos membros mais velhos de um agrupamento social sobre suas vivências e experiências, de maneira a permitir a permanência cultural deste grupo.

3 A expressão oralitura é utilizada por Martins $(1997 ; 2006)$ para problematizar a maneira como nos Congados a oralidade inscreve nos corpos e espaços as memórias e os saberes da Festa de Nossa Senhora do Rosário. Ao inscrever-se nos corpos e espaços, como propõe a autora, a oralidade ganha a dimensão de texto, corporificando/cartografando ritualisticamente os muitos matizes da cultura negra em terras brasileiras; constituindo-se em oralitura. 
da população. Como apontam os dados do Instituto Brasileiro de Geografia e Estatística (IBGE), Viçosa, se comparada às outras escalas de análise espacial, possui percentagem de idosos inferior à Zona da Mata mineira, ao estado de Minas Gerais, à Região Sudeste e ao Brasil. No entanto, se interceptados os dados de população negra aos de população com idade igual ou superior a 60 anos, Viçosa possui percentagens superiores a todas estas escalas de comparação ${ }^{4}$. Esta realidade mostra a força da presença da população negra na constituição do município, o que justifica a busca de um entendimento mais minucioso sobre seu processo de formação nesta cidade, bem como das formas espaciais e temporais em que se dão os cotidianos desta população incluindo, além das questões de reprodução material, elementos da ordem do simbólico, da representação e do imaginário.

Para a geografia, buscar problematizar formas de organização da realidade baseadas na cultura popular constitui-se em uma questão de relevância por proporcionar aquilo que está no cerne da sugestão de Martins (2006), qual seja, de que nem todas as sociedades ou grupos sociais produzem da mesma forma suas espacialidades. No caso do Congado, a organização espacial pauta-se não necessariamente numa lógica intelectual baseada na racionalidade ocidental. Por vezes, corpo e oralidade é que dão forma ao espaço, que neste caso é tido como um palimpsesto, permitindo que sejam circunscritas, por diversas vezes, as reiterações trazidas pelas performances do Congado ao buscar instaurar seu lugar festivo.

O esforço desta pesquisa reside, pois, em tentar trazer à tona formas de organização espacial que muitas vezes não são possibilitadas a partir dos referenciais com os quais estamos habituados a tentar apreender as espacialidades humanas. A constituição desta pesquisa vai, desta maneira, ao encontro das proposições de Boaventura de Sousa Santos (2006), pois pretende contribuir para maior expressão política de saberes e práticas sociais negadas ou negligenciadas pela ciência moderna ocidental, que acusa de ignorante, residual, localista ou inferior as formas de organização do espaço que não se pautam na racionalidade ocidental e moderna. Ao nos aproximarmos das démarches boaventurianas, pretendemos contribuir para mostrar como uma série de saberes e práticas são esvaziados de valor pela ciência como construtores do mundo. Contrapondo a concepção que negligencia determinadas práticas espaciais, buscamos mostrar como os festejos do Congado atuam na produção e organização de lugares, territórios e paisagens, tentando com isso minimizar o desperdício da experiência social de uma série de sujeitos subjugados e subalternizados pelo saber científico hegemônico.

\section{AS NARRATIVAS DE VIDA ESPACIAIS}

Lindón (2008) chama atenção para como as novas disposições dos processos sociais têm influenciado de forma benéfica o debate teórico dentro da epistemologia da geografia. De acordo com a autora, os debates teóricos retomados nas últimas três décadas do século XX na geografia têm trazido um rejuvenescimento para nossa ciência e aberto novas possibilidades de apreensão da realidade.

A emergência da concepção de espaço como uma construção social, em detrimento da perspectiva do espaço como um produto social ou como algo experimentado, seria um dos fatores responsáveis pelos muitos ganhos teóricos e metodológicos no debate geográfico recente. Para Lindón (2008), a perspectiva do espaço como um produto social, que traz em suas postulações grande ênfase no material, teria formulado uma concepção do espaço apenas como um objeto, uma coisa ou um fato social. Por sua vez, a perspectiva do espaço vivido, representado ou experimentado, trouxe grandes dificuldades metodológicas para a geografia, por colocar toda sua ênfase na perspectiva do sujeito, não possibilitando a apreensão do espaço para além de sua experimentação. A articulação de ambas as dimensões do espaço seriam, para a autora, uma possibilidade mais abrangente para sua abordagem. Quando o espaço é pensado da maneira como é construído, tanto as dimensões materiais quanto as de vivência poderiam ser colocadas em evidência. Estas geografias construtivistas seriam, pois, um esforço de apreensão do espaço evitando os exageros materialistas e as exacerbações idealistas.

Estas geografias construtivistas, que têm se

4 De acordo com os dados do censo demográfico brasileiro do ano 2000, enquanto em Viçosa o percentual de pessoas com idade igual ou superior a 60 anos é de 8,16\%, na Zona da Mata mineira esta percentagem é de 10,9\%; no estado de Minas Gerais de 9,07\%; na região Sudeste de $9,29 \%$ e no Brasil de $8,55 \%$. Entretanto, a cidade possui $1,29 \%$ de sua população que se autodeclara negra e com idade igual ou superior a 60 anos, enquanto na Zona da Mata mineira este percentual é de 1,12\%; no estado de Minas Gerais de 0,8\%; na Região Sudeste de $0,63 \%$ e no Brasil de 0,59\%. Estes dados estão disponíveis em <http://www.sidra.ibge.gov.br>, acesso em: 23/10/2008. 
apresentado como possibilidades de renovação do debate geográfico contemporâneo têm trazido, entretanto, grandes desafios metodológicos à nossa ciência. Tem-nos sido colocada a questão de como apreender a experiência espacial do outro para melhor compreendermos a forma de organização das espacialidades humanas. Lindón (2008) argumenta que como o interesse da geografia não é somente o de conhecer a experiência do outro, mas também e fundamentalmente o seu espaço construído, vivido, representado, percebido e experimentado; deparamo-nos com o desafio de erigir uma forma de produzir informações através de instrumentais metodológicos adequados para abordar as espacialidades do outro.

Lindón (2008) sugere que um caminho possível a ser trilhado para começarmos a resolver esta questão seria o de nos aproximarmos mais seriamente da teoria social e das metodologias qualitativas de análise espacial. Neste caminho de proposições, três alternativas se colocam como factíveis para ajudar na captação das ações e práticas sociais que os sujeitos lançam mão para organizar seus lugares. A primeira seria a observação das práticas espaciais dos sujeitos, a segunda problematizar as espacialidades dos sujeitos através da interpretação de imagens diversas e a terceira alternativa seria tentar abordar as constituições espaciais dos sujeitos através dos discursos que eles constroem sobre suas ações e práticas. Das três possibilidades a última parece ser a que nós geógrafos menos temos nos incursionado durante a evolução de nossa ciência. A observação em campo e a tomada dos territórios e paisagens como uma fotografia foram amplamente utilizadas, a perspectiva de abordagem do espaço através das construções narrativas dos sujeitos foi, entretanto, pouco realizada. Paradoxalmente, a discursividade se apresenta como uma das maiores possibilidades para compreendermos ou entrar em contato com a experiência espacial dos sujeitos.

Bruner (2001) argumenta que o modo narrativo de pensamento é uma possibilidade pertinente e apropriada para estabelecermos uma atividade séria de investigação partindo da memória discursiva como fonte de conhecimento científico; de uma interpretação narrativa da realidade. Nesta perspectiva, a aproximação ao pensamento narrativo de sujeitos a respeito de suas espacialidades é uma maneira plausível de buscarmos compreender a constituição da vida de lugares, paisagens e territórios, de se conhecer biografias espaciais.

É neste sentido que as narrativas de vida espaciais podem se constituir como um parâmetro interessante para o balizamento de biografias espaciais, onde a constituição de um lugar se torna melhor entendida quando relacionada às vidas que o animam e que por ele são animadas. Lindón define bem a ideia ao dizer que:

[...] una narrativa de vida espacial es um relato organizado y secuencializado espacio-temporalmente de experiencias vividas por el sujeito en ciertos lugares. Es um relato en el cual el lugar - con toda su singularidad - se hace parte de la experiencia allí vivida, influye de alguna foma en la experiencia, le imprime una marca. (LINDÓN, 2008, p. 20)

Abordar a experiência espacial de sujeitos através de uma interpretação narrativa não significa, entretanto, a simples anotação ou sintetização de fatos narrados. Como alerta Lindón (2008), a narrativa biográfica espacial se constitui numa co-produção entre o narrador e o investigador. A este último cabe o papel de analiticamente identificar o que o discurso narrado ou silenciado diz sobre a prática espacial de sujeitos, buscando nas falas, reticências, esquecimentos e silenciações o que de densidade há nas práticas espaciais e nos discursos tidos como aparentemente banais.

Outra questão espinhosa surge neste ponto, o ceticismo que pode trazer o tratamento epistemológicocientífico aos elementos da narrativa, como alerta Bruner (2001). Somos obrigados a nos questionar a respeito da maneira pela qual podemos construir uma atividade de pesquisa científica sobre eventos memoriais sem que caiamos no sentido simplista de informar ou noticiar algo. Avançando um pouco mais, temos ainda de nos interrogar sobre a forma como podemos construir uma narrativa sem que subtraiamos toda análise psicológica e filosófica que exige uma atividade científica, mas que despovoa ao leitor ou ao ouvinte de espaços para a imaginação e ornamentação daquilo que está sendo narrado, pressuposto básico da arte de narrar. Se, como afirma Benjamin (1975), as melhores narrativas são aquelas que se aproximam dos relatos orais, como construir uma narrativa acadêmica ou relatórios científicos sem que se perca a poesia dos fatos na maneira como os observamos na realidade?

Como nos aponta Tuan (1983), embora seja difícil comunicar experiências íntimas que desenvolvemos com coisas e pessoas, pela escassez de vocabulário para expressar aquilo que só está na dimensão do sentir e não necessariamente do racionalizar; o significado de nossas experiências não se restringe a um território privado e impenetrável. Podemos compartilhar nossas experiências com o outro, a partir do relato de nossa vivência, tornando nosso interlocutor capaz de nos compreender a partir do reconhecimento daquilo que compartilham conosco de certa maneira. A questão 
então é a de que além de uma re-configuração das abordagens teóricas e metodológicas que temos de fazer para aproximação das experiências espaciais dos sujeitos sociais, faz-se necessário uma re-formulação do modelo de divulgação ou inscrição de nossas interpretações das narrativas de vida espaciais.

Hissa (2002), numa refinada proposição de reconfiguração dos aspectos formais da escrita científica em geografia, sugere o gênero ensaístico como uma interessante possibilidade textual de construção de um método de pensamento e de transcrição reflexiva de atividades investigativas. Para o autor o ensaio é, como estilo textual e exercício de vida,

[...] um momento e uma possibilidade de criação, liberdade concedida à imaginação, à inventividade, à adaptação do como fazer melhor. [...] à dúvida que permite o avanço modesto na direção do inatingível, à dúvida que admite a complexidade e exterioriza diversas e ricas possibilidades de caminhos verdadeiramente consistentes em toda a sua aparente imprecisão. (HISSA, 2002, p. 171-172).

É este o nosso exercício neste texto, construir ensaisticamente uma narrativa que permita comunicar de modo analítico como um evento festivo pode, na dimensão do lugar, se constituir como uma biografia espacial. Que conta e reconta aos participantes da Irmandade de Negros de Nossa Senhora do Rosário de São José do Triunfo os processos de sua constituição espaço-temporal através dos aspectos memoriais narrativamente trazidos pelos festejos do Congado.

\section{A IRMANDADE DE NEGROS DE NOSSA SENHORA DO ROSÁRIO DE SÃO JOSÉ DO TRIUNFO: SUJEITOS DE PESQUISA E DA FESTA}

A Irmandade de Negros de Nossa Senhora do Rosário de São José do Triunfo, distrito localizado na cidade de Viçosa-MG, está estabelecida na mesorregião da Zona da Mata Mineira, porção espacial do estado de Minas Gerais que teve as origens de sua economia orientadas principalmente para a agropecuária, possuindo em função disso, nos dias atuais, grandes traços desta economia agrária e dos modos de vida rural. Lamas et al. (2008) explicam que esta mesorregião teve grande importância na história do Brasil, por se estabelecer como a região provedora de grande parte dos suprimentos demandados pela região mineradora de Minas Gerais no auge do Brasil colonial. Sua formação geográfica é, pois, em parte, fruto desta grande relação com as áreas auríferas de Ouro Preto e Mariana, municípios que tiveram sua opulência sustentada pela exploração de minas de ouro.

Paniago (1990) salienta que a ocupação da microrregião de Viçosa por populações negras efetuou-se pelas emigrações provenientes das decadentes minas de ouro de Mariana e Ouro Preto na segunda metade do século XVIII, movimento que trazia consigo os escravos que trabalhavam nas minas. O estabelecimento dos antigos empresários auríferos em Viçosa e adjacências, ainda segundo Paniago (1990), efetivou-se pela formação de fazendas com a base econômica orientada para a pecuária e as lavouras de café.

O distrito de São José do Triunfo figurou neste cenário como importante território para a fixação de negros. Segundo pesquisa realizada pelo Núcleo Interdisciplinar de Estudos de Gênero - NIEG/UFV5, alguns poucos moradores antigos ainda têm a memória da condição escrava. Segundo contam os moradores, São José do Triunfo tem o apelido de "Fundão" porque o lugar era caminho de fuga de escravos, onde há uma grota que na época servia de refúgio; grota essa também chamada de "fundão".

Paniago (1990) ressalta ainda que a população negra que se fixou na região de Viçosa é de origem do grupo Bantu, população negra formada por inúmeras tribos do grupo Angola-Congolês e de grupos da ContraCosta. A autora apresenta como evidência da ocupação desta população na região de Viçosa as "sobrevivências culturais" encontradas por ela em pesquisas na década de 1980. Embora algumas outras manifestações desta cultura, como a dança jongo, ainda sejam evidentes, é, diz Paniago, nos grupos de Congos, Congadas ou Congados que fica mais perceptível a presença do Bantu, sobretudo nos distritos de São José do Triunfo e de Cachoeira de Santa Cruz.

O Congado, como define Roberto (2000), é o termo que designa os cortejos de negros escravos que reverenciavam santos católicos em festas, rituais e cerimônias de coroação de rei e rainha Congo. O Congado tem origem luso-afro-brasileira, uma vez que foi o catolicismo português que ofereceu a devoção a Nossa Senhora do Rosário. A Igreja, no Brasil, reforçou essa crença e os negros deram forma ao culto e à festa por intermédio de elementos africanos. (MARTINS, 2002)

5 Trabalho de Extensão sobre Saúde Reprodutiva Feminina, realizado pelo NIEG - Núcleo Interdisciplinar de Estudos de Gênero em 2000, junto aos agentes comunitários de saúde do PSF (Programa Saúde da família) e da população feminina de São José do Triunfo, distrito de Viçosa-MG. 
Ao citar Brandão, Roberto esclarece sobre a permanência da Festa do Rosário mesmo depois de séculos de manifestação.

Congos, congadas, afoxês, taieiras, reinados, maracatus, são alguns dos vários nomes de grupos rituais que, pelo menos desde o século XVII, continuam a sair às ruas, sobretudo as das cidades de economia ainda rural, em busca de adro e da nave das Igrejas de seus santos, ou das casas de seus pares e senhores.

[...] Dificilmente haverá em tantas cidades do País uma outra festividade ritual, popular e católica, tão presente ainda entre os momentos de fé coletiva e devoção em Festa de igreja como a congada. Dificilmente também um outro tipo de prática religioso-folclórica será como o congo tão diretamente associada a grupos de negros de confissão católica. (BRANDÃO apud ROBERTO, 2000, p. 1).

Martins (2006) caracteriza esta manifestação como um sistema religioso que se hibridiza entre as orientações afro da religiosidade negra brasileira e o catolicismo popular de matriz europeia. Durante as celebrações em torno da figura de N. Sra. do Rosário, os grupos de congo performatizam espacialmente, através de suas danças, cantos e celebrações, as travessias de negros da África para as Américas. Com suas narrativas mitopoéticas, os grupos consagram o espaço ao visitar lugares, ritualizando suas memórias de cativeiro, de travessia da África para o Brasil e de recordação do espaço além-mar. Estes grupos de congadeiros, ao celebrarem suas memórias, como salienta Martins (2006), grafam no espaço, com seus corpos, a dramaturgia de passagem de uma condição de morte (escravidão, silêncio, imobilidade) para uma de vida (liberdade, resistência, voz e movimento). Em nosso entender, são criadas, assim, geo-grafias memoriais.

Em São José do Triunfo, a Festa do Rosário revela fortes relações entre as dimensões de espaço e tempo e o fenômeno da memória. Tais relações podem ser visualizadas no discurso daqueles que vivem a festa desde sua "transferência" para o local. Segundo seus participantes mais antigos, esta transferência ocorreu por volta do ano de 1930, quando os avós dos atuais Rei Congo e Capitão da Banda levaram-na de Viçosa para o Fundão, data que coincide com o início de formação do Distrito. Seu Dola e Seu Zeca, tidos pelos participantes do Congado como os que guardam o maior conhecimento da festa religiosa no local, e nela ocupando respectivamente as funções de Rei Congo e Capitão da Banda, acentuam, em seus discursos e memórias sobre a festa, indissociável relação entre os lugares das celebrações, sua história e o Congado.

Como observamos, a Festa do Rosário mais do que recolocar em relevo os espaços e tempos que viveram estes guardiões da memória - constituindo em importante fonte documental para textualizar a constituição geográfica e histórica do local -, possibilita a composição de novas dinâmicas nos espaços que por hora já se organizam segundo novos usos e agentes. Na medida em que é passada para as novas gerações, as celebrações do Congado possibilitam transmitir uma cultura - que já permanece por séculos -, sendo revificada através do modo de uso e significação dos espaços. Ou seja, a festa se refaz enquanto história e cultura através do modo como aciona os lugares em que se realiza. Nos momentos de festividades, é considerável o número de jovens e crianças no evento. Halbwachs esclarece sobre o caráter (re)criador da memória:

\begin{abstract}
A história não é todo passado, mas também não é tudo aquilo que resta do passado. Ou, se quisermos, ao lado de uma história escrita, há uma história viva que se perpetua ou se renova através do tempo e onde é possível encontrar grande número dessas correntes antigas que haviam desaparecido somente na aparência. [...] Os grupos, no seio dos quais outrora se elaboravam concepções e um espírito que reinara algum tempo sobre toda sociedade, recuam logo e deixam lugar para outros, que seguram, por sua vez, durante certo período, o cetro dos costumes e que modificam a opinião segundo novos modelos. (HALBAWACHS, 1990, p. 71).
\end{abstract}

É neste sentido, que intitulamos este artigo de Geo-Grafias da Memória e acionamos a imagem trazida recorrentemente pelos sujeitos desta pesquisa em diversas entrevistas. Baseando-se na figura alegórica de Chamas de candeeiros os guardiões da memória, ao relatarem a história da festa, dizem que é muito bonito lembrar-se de tudo pelo que já passou o Congado em São José do Triunfo.

Hoje nós fazemos festa é iluminados por luz de poste, mas antigamente nós colocávamos é em bambu umas chamas para iluminar nossas passagens pelas ruas, eram os candeeiros que iluminavam nossa festa. (Seu Zeca, Diário de Campo, 12/09/2006) ${ }^{6}$.

6 O diário de campo consistiu num instrumental metodológico que nos permitiu a anotação dos relatos dos participantes do evento em questão realizados durante entrevistas de nossa pesquisa, bem como num exercício de descrição densa dos acontecimentos e das dinâmicas do distrito que observamos em acompanhamento ao grupo de Congado. Tal instrumento permitiu que fossem realizadas a apreensão das referências espaciais dos grupos em análise e o delineamento das tensões entre sujeitos participantes da festa e das simbolizações e conflitos realizados pelo/no lugar. Este diário de campo está publicado no site do Grupo Lux Festa do IESA/UFG e pode ser acessado pelo endereço <http://www.iesa.ufg.br/festaspopulares/?id_pagina=1225829502\&site_id=49> 
É neste entendimento de que permanece viva a chama da memória e o fulgor da história e da geografia do lugar, na medida em que a festa os re-alimenta como nos candeeiros, mas neste caso com o óleo e a querosene da Festa do Rosário; com espaço e tempo transformando-se em memória, a memória transformando-se em agente produtor do presente, através da oralidade e das linguagens em ação -, que pudemos identificar as formas como a festa acaba por funcionar como elemento resguardador das memórias do grupo social que dela participa, transmitindo narrativamente os percalços da história espacial da população negra no território em questão às novas gerações que participam dos festejos do Congado. Assim, vislumbramos que a dimensão memorial trazida pela festa atua na construção e manutenção da coesão no grupo, que se organiza segundo os mesmos princípios e propósitos reivindicativos para assegurar as condições para sua existência, como no período da escravidão, em torno dos quilombos, ou na atualidade, no sentido de permanência por adesão cultural do grupo.

\section{O LUGAR FESTIVO COMO BIOGRAFIA ESPACIAL}

Dentro da diversidade de categorias analíticas da ciência geográfica o conceito de lugar figurou como aquele que mais apoio nos ofereceu para pautarmos nossa apreciação do evento festivo em questão.

Lugar nesta pesquisa é entendido como a dimensão do espaço com a qual as pessoas estabelecem relações simbólicas de existência e, portanto, como a porção do espaço apropriável para a vida pelas pessoas através de seus corpos (CARLOS, 1996). Lugar se opõe à noção de espaço por este conceito estar muito mais ligado à ideia de movimento, liberdade e de ameaça, enquanto a noção de lugar se aproxima muito mais dos sentimentos de pausa, segurança e estabilidade (TUAN, 1983).

Pelas possibilidades analíticas da categoria geográfica e da dimensão humana de lugar, Ferreira (2003) sugere que um bom parâmetro para a compreensão e assimilação do evento festivo pela geografia é seguir o acúmulo interpretativo deste conceito. Este autor sugere que o espaço pensado como "lugar festivo" permite entender o sentido de lugar e do evento festivo. O lugar festivo seria, na ótica deste autor, uma das manifestações espaciais de conflitos que procuram exercer o poder sobre o espaço através do discurso, elegendo-o como espaço da festa. O ato de festejar teria, pois, uma dimensão eminentemente espacial, uma vez que controlar discursivamente um dado espaço e concebê-lo como festivo por meio de tensões e conflitos pelo poder seria uma dimensão fundamentalmente do festar.

As delimitações do lugar festivo não passariam, pois, simplesmente pelo recorte espacial da maneira como estamos acostumados a concebê-lo, qual seja, de conquista de espaços e de construção de suas hegemonias através das relações de classe e pela materialidade dos territórios. A delimitação do espaço da festa é pensada aqui a partir de constantes tensões que disputam um espaço simbólico. O que define o lugar aqui pertencente a um ou outro grupo são os discursos sobre suas significações e seus valores simbólicos. Desta maneira, é "dono" do espaço aquele que detém o discurso e os saberes sobre ele: quem possui a memória da paisagem e do lugar o domina, pois, é este que lembra quem define o que deve ser lembrado e o que deve ser esquecido.

Desta maneira, o lugar festivo se constitui como uma instituição discursiva que, através das narrativas trazidas pelos rituais do Congado, define uma maneira de se conceber a história de vida de um lugar. A memória festiva é, neste caso, fruto de uma disputa de sentidos que negocia e elege as narrativas válidas sobre a biografia de um espaço.

Neste ponto de vista, podemos arriscar em dizer que $o$ ato de festejar se torna de fato festa quando se apropria dos lugares. Uma vez que a festa só existe enquanto disputa pelas significações que dão coerência e sentido em festejar para e sobre algo, e como muito bem define Ferreira (2003, p. 12), "a batalha retórica pela definição da festa só torna, na verdade, um afrontamento, ou seja, uma festa, quando a tensão se espacializa."

A categoria de lugar se apresentou, desta maneira, como bastante apropriada para o estudo dos espaços memoriais, uma vez que o lugar se mostra como dimensão de estreitas relações com a construção de identidades a partir das lembranças que se apoiam sobre espaços.

A respeito da noção de memória concordamos, com as proposições de Halbwachs (1990) e Pollak (1992), que entendem a memória coletiva como fruto do choque das memórias individuais em pontos comuns e de negociações a fim de formar um aparato que permita a constituição de lembranças comungadas por um grupo, evidentemente constituído de sujeitos com parte de suas lembranças não pertencentes a todos.

Para Pollak (1992), este processo de negociação da memória faz, inclusive, parte do processo de construção do sentimento de identidade. Seria, então, a memória um elemento não só semelhante à identidade, 
mas constituinte desta, na medida em que se aproximam enquanto tentativa de negociação e da reconstrução de si. Desdobrando a análise, o autor utiliza a seguinte argumentação:

Se assimilarmos aqui a identidade social à imagem de si, para si e para os outros, há um elemento dessas definições que necessariamente escapa ao indivíduo e, por extensão, ao grupo, e este elemento é, obviamente, o Outro. Ninguém pode construir uma auto-imagem isenta de mudança, de negociação, de transformação em função dos outros. A construção da identidade é um fenômeno que se produz em referência aos outros, em referência aos critérios de aceitabilidade, de admissibilidade, de credibilidade, e que se faz por meio da negociação direta com os outros. Vale dizer que memória e identidade podem perfeitamente ser negociadas, e não são fenômenos que devam ser compreendidos como essências de uma pessoa ou de um grupo. (POLLAK, 1992, p.5).

Há, portanto, uma inegável dimensão de tensionamento na constituição dos discursos memoriais e sentimentos identitários. Discursos e sentimentos estes que encontram no lugar festivo um instrumento para sua concretização e balizamento.

Defendemos, ainda, que uma teoria a respeito da categoria lugar deve ser compreendida numa dimensão relacional, quer dizer, na medida em que este conceito é entendido como ponto de encontro de redes de conexões sociais, movimentos e comunicações; ou ainda numa noção um pouco mais complexa, que teoriza que o espaço só pode ser entendido enquanto rede, em que um local só se torna lugar na medida em que é colocado em relações de similaridades ou distinções com locais situados em outros tempos ou espaços (FERREIRA, 2003). No Congado esta se torna uma afirmação importante, por seus festejos trazerem recorrentemente à tona as memórias de espaços-tempo do continente africano e do cativeiro durante o período colonial no Brasil.

De fato, o que ocorre em São José do Triunfo é uma série de disputas e batalhas de discursos na busca da afirmação dos lugares dos distintos grupos e singularidades ali existentes. Além do Congado, há no distrito uma série de coletividades buscando afirmar discursivamente o espaço de símbolos pertencentes a seu grupo, existindo ainda os grupos externos a São José do Triunfo que oferecem certos riscos à coerência das significações conferidas aos objetos pelos participantes do Congado. Há, por exemplo, a coexistência de Igrejas de culto protestante no local. A casa de Seu Dola, local onde ocorre uma série de eventos da festa, é separada da Igreja Assembléia de Deus apenas por um muro. Nos relatos coletados em campo há falas que expressam o caráter de tensionamento ocorrido entre o grupo de congadeiros e esta igreja:

A divisa entre a casa de Seu Dola e a Igreja Assembléia de Deus é feita somente por um muro. Questionei [a Seu Dola e Seu Zeca] se no dia da Festa a Igreja... $E$ antes de eu terminar de elaborar a pergunta eles já se adiantaram em responder que "Não! A Igreja não se envolve com nada, eles até param para olhar, mas não cobiçam nada. Eles não amola nós nem nós amola eles.

Questionei então se os cultos eram nos mesmos horários habituais no dia da Festa. Seu Zeca foi quem explicou: "Quando saímos com a alvorada ainda não tem culto, quando voltamos, sete, oito horas... eles param o culto e vêm ver nóis."

No dia doze pra treze [um dos momentos festivos do calendário do Congado, que ocorre no mês de maio] também não tem problemas. "Começa em outro horário, não atrapaia não, porque se atrapaiasse nós compunha com eis, né?"Questionei o que era compunha, Seu Zeca disse que "era assim, tomo tudo pertinho ali, se eles atrapaisse nóis, nós chamava eles pra fazer uma concórdia com eis, propô para eis, né? Pra que es mudasse a hora daques trabaio deis ou baixasse aqueles trabaios deis, pra nóis não ficar prejudicado e eis também não. Por quê? O nosso [Congado] é espaçoso, é hoje e as vez passa é quatro, é cinco, é seis mês... Eis tem todo dia. Então, eis pode pará hoje e amanhã eis pode fazê; o nosso é hoje, amanhã nóis num vâmo fazer. Então nóis compactua com eis assim: Eis fazesse mais cedo ou então mais silencioso, né? Pra gente fazer o movimento da gente mais sossegado. Mas então num atraipaia e a gente deixa assim mesmo do jeito que tá. Eis num vem atrapaiá nóis e nóis também num vai atrapaiar eis, então... Agora, se atrapaiasse, nós ia ter que fazer com eis, concordar com eis, propor uma concorda com eis." (Diário de Campo, 27/06/2007)

Conversei com um pastor da Assembléia de Deus, Igreja vizinha a casa de Seu Zeca. Questionei sobre a relação da Festa, que é confessamente católica, com sua religião. O pastor disse não haver o mínimo atrito e que a expressão religiosa é um direito assegurado pela constituição. Disse ser a Festa mais uma forma de buscar Deus, embora sua Igreja não seja favorável à utilização de imagens e a adoração de santos, além da bíblia condenar tais práticas. (Diário de Campo, 15/10/2006)

Entre a Igreja Católica e o grupo de Congado também é possível perceber certas dicotomias, como na cena abaixo relatada. Ao proferir dizeres que vão 
em sentido contrário às reivindicações da Irmandade, que em suas músicas entoa cantos que expressam o descontentamento com os eventos da colonização, o caráter de tensionamento é mais uma vez expresso. Nos relatos há falas que sugerem tais questões:

Na hora das preces [durante a Missa Conga realizada na Igreja Católica do distrito] um fato interessante. A celebração parecia atender às determinações dos folhetos da Igreja para cada dia do ano (evangelho, leitura e dizeres das preces escolhidas). A leitura e o evangelho não possuíam nenhuma coerência com a festividade celebrada, estes momentos soaram mesmo como frios, por tratar de assuntos que em nada remetiam ao evento festivo. As preces, porém, não simplesmente possuíam "coerência" com o momento; embora parecesse que sem planejamento específico para o evento, estas faziam referência à expansão do cristianismo pelo mundo.

Numa mistura entre linguagem poética e de texto informativo, de maneira bem pouco comum nas missas que já presenciei, as preces utilizavam-se de metáforas e dados estatísticos para descrever e fazer constatações de como o cristianismo avança ao longo da história pelo planeta.

A primeira fala iniciou dizendo que quando no Brasil o sol se põe, ele nasce na Austrália. A partir daí se apresentou alguns dados que revelam a situação dos cristãos na Oceania e pediu-se que rezássemos por estes povos. Em seguida, falou-se do continente asiático; disseram qualquer coisa sobre o sol e pediuse que rezássemos de modo especial pelos asiáticos em função deste continente abrigar a maior parcela da população mundial e em detrimento a menor percentagem de cristãos no mundo em relação aos números absolutos da população. Pediu-se também que rezássemos pelo continente africano, ainda pouco cristão. Ao falar da Europa solicitaram que recordássemos com gratidão daqueles que trouxeram para nós a palavra de Cristo, "aqueles que nos evangelizaram". Falaram ainda sobre a América, onde o cristianismo é bastante difundido. (Diário de Campo, 14/10/2007)

Quanto às ameaças externas ao grupo, a derrubada das Igrejas no centro da cidade de Viçosa em meados do século passado é indicativa da questão. O que os indícios apontam é que a Festa de Nossa Senhora do Rosário chegou ao distrito num deslocamento gerado por batalhas discursivas ocorridas na área central do município do qual São José do Triunfo faz parte. Segundo os guardiões da memória, a festa antes de ocorrer no Fundão já acontecia em toda a região, inclusive em Viçosa, onde era organizada por seus avós. O que supomos é que a festa tenha "perdido" na área central de
Viçosa a batalha retórica pelo lugar. Os indícios são a troca do nome da Igreja Matriz e de algumas das Igrejas comunitárias da cidade, que perderam o nome de Nossa Senhora do Rosário, como é o caso da igreja situada no Bairro de Fátima que hoje é denominada Igreja Nossa Senhora de Fátima do Rosário, e de uma das praças centrais da cidade de Viçosa, que hoje possui o nome de Praça do Rosário em função de uma Igreja que existiu naquele local até o início da década de 1960. Nos registros feitos em entrevistas há situações que corroboram com estas questões:

Seu Dola disse a ela [Dona Maria do Nascimento, sua irmã] que eu comentei da Igreja do Rosário derrubada em Viçosa, que ela deveria lembrar, já que carregou muita bandeira na cidade. Ela disse lembrar, mas não deu muita atenção, falou mais da Rua Seca (hoje Morro do Pintinho). Seu Zeca e Seu Dola disseram lembrar de terem ido à Igreja derrubada, durante a missa de sétimo dia de Virgílio (?). "É uma boa lembrança essa!". Conclui Seu Dola.(Diário de Campo, 27/06/2007)

A Rainha Conga era quem explicitamente comandava a fala, era ela quem dava rumo para a conversa, embora Eliana tentasse sempre acompanhá-la e fazer comentários em torno de suas falas.

Quando falaram no nome de Zé Felipe, começaram a falar dos convites que este fazia para que as pessoas fossem até Viçosa assistir o Congado. Neste momento começaram a falar da Igreja do Rosário que existiu em Viçosa, "e era uma Igreja petitinha do Rosário na Pracinha do Rosário". Eliana disse isto com tanta segurança que deu impressão de que ela havia conhecido a Igreja antes de ser derrubada, o que era improvável por sua idade, então questionei se ela havia conhecido a Igreja, ela respondeu com um ar de que não fazia a menor diferença ter visto ou não a Igreja para que esta estivesse em sua memória: " - Não, o povo é que conta." Dona Maria falou mais sobre a Igreja: " - É, era uma Igreja pequenininha, feita de ripa. Lá tinha Santa Efigênia, São Benedito e a Senhora do Rosário".

Questionei sobre o motivo da derrubada da Igreja, Dona Maria disse que foi em função da construção da pracinha, por vontade do prefeito. Perguntei sobre o posicionamento do padre, Dona Maria respondeu que:

"Para deixar Viçosa mais bonita, né meu filho?! Pra deixar Viçosa mais bonita desmanchou a Igreja. Agora, cadê os santos que desapareceu tamém? Os santos desapareceu, porque Santa Efigênia e São Benedito você não sabe onde é que está. É preto, né!!! (risos dela). O Senhor dos Passos fica lá na Igreja dos Passos. A Nossa Senhora do Rosário diz que tá lá na Santa 
Clara, quem falou comigo é uma moça que mora lá, mas eu não tenho certeza.".

Dona Regina questiona à Dona Maria sobre a Nossa Senhora do Rosário que existe na Igreja Matriz. Esta última diz saber da existência dela, mas diz que a outra era mais... Dona Regina é quem completa: "- Preparada." (Trecho das falas proferidas durante o Mapeamento Histórico em realização ao Diagnóstico Rápido Participativo. Diário de Campo, agosto de 2008).

A fixação da Festa do Rosário no Fundão também não parece ter sido efetivada de forma muito tranquila. De acordo com relatos dos guardiões da memória, embora a festa tenha se deslocado para o distrito em 1937, só recentemente este evento parece ter adquirido relações pacatas com a Igreja católica.

Embora a relação de tensionamento da Festa do Rosário com a Igreja Católica hoje aparente ser bem mais sutil, é importante fazer alguns apontamentos. São, de fato, visíveis as concessões feitas pela lgreja ao momento festivo. Ela permite, por exemplo, que, por vezes, haja a substituição do pároco local por um padre negro na celebração de missas durante a festa, que a banda de congo adentre no espaço sacro da nave da Igreja batucando seus tambores e que os participantes de maior hierarquia na festa ao fim da missa tenham direito a proferir seus dizeres, que na maior parte das vezes são enunciados em algo muito distante do português e muito mais próximo das línguas de origem africana. A relação apresenta, entretanto, uma série de atritos. Fica claro pela estruturação da missa que quem a dirige é a Igreja Católica, que concede, de acordo com sua permissão, voz ao grupo de congadeiros. A recíproca também se dá nesta dimensão. Embora o grupo de Congado professe claramente suas filiações cristãs, a missa é tomada de momentos que parecem se distanciar disso. As falas proferidas ao fim da missa por Seu Zeca e Seu Dola caracterizam muito bem este fato, eles tiram totalmente o domínio da Igreja no momento em que começam a falar numa outra língua e num ritmo e tom que se aproxima significativamente de outras formas de culto religioso.

Outra noção importante para o entendimento do sentido de lugar festivo, que já chamamos atenção anteriormente no texto, é a compreensão de que a dimensão do lugar emerge a partir do reconhecimento de suas singularidades ante outros espaços e pelas relações de similaridades com locais situados em outros tempos ou espaços. As falas de Seu Zeca e Seu Dola e outro antigo participante da festa, Juquita, mais uma vez é o que sustenta nossas proposições. Suas constantes defesas de que o Congado do Fundão pos- sui singularidades que o torna diferenciado e o coloca numa posição distinta de status em relação a outros, são indicativos desta necessidade de construir o lugar da festa em São José do Triunfo a partir da comparação, negação ou afirmação de outros lugares, situados em outros tempos e espaços. Em entrevista,

Juquita disse que o Congado atualmente existe por toda a região: em Cachoeirinha, São Miguel, Paula Cândido, sendo, porém, "o do Fundão mais organizado, o povo gosta mais do daqui." (Diário de Campo, 12/09/2006)

Assim, para a caracterização do lugar da festa no Fundão, é necessário se reportar memorialmente aos distintos lugares por que passou a festa até chegar àquele espaço e aos novos lugares em que hoje se dispõem naquele local.

Espaço e tempo são, desta maneira, importantes partes constituintes da memória, por serem dimensões sociais do processo de formação e evolução desta. Halbwachs salienta que:

Como auxiliares de nossa memória, os acontecimentos
históricos não desempenham um outro papel senão
as divisões do tempo assinalados em um relógio, ou
determinados pelo calendário. Nossa vida se escoa em
um movimento contínuo. Mas logo que nos voltamos
para aquilo que já se desenrolou, sempre nos é pos-
sível distribuir as suas diversas partes entre os pontos
de divisão do tempo coletivo que encontramos fora de
nós, e que se impõe de fora a todas as memórias indi-
viduais, precisamente porque eles não têm sua origem
em nenhuma delas. O tempo social assim definido
seria inteiramente exterior às durações vividas pela
consciência. (HALBWACHS, 1990, p.60-61).

O lugar pensado como espaço que aproxima paisagens e memórias, revela a festa como evento propício para análise das memórias coletivas em torno da paisagem e dos lugares. A festa com seu poder pedagogizante, por possuir certa regularidade temporal e um caráter ritualístico e de repetição, fixa na memória de seus sujeitos participantes e ensina aos novos integrantes do grupo seus valores e crenças, criando certas paisagens mentais e construindo a memória espacial do grupo a ela vinculado.

Este sentido de festa como pedagogia, quer dizer, como evento social que trabalha na manutenção da memória de acontecimentos histórico-culturais e de espaços, pode ser bem apreendido pela contribuição de Giacalone (1998). Esta autora defende a função educativa da festa como a de uma linguagem, em suas 
mais distintas formas: escrita, falada, corporal, musical, visual; capaz de renovar ou manter as práticas simbólicas dos grupos e de transmitir aos novos participantes da festa seus valores, crenças, informações e saberes. Neste ponto de vista, pode ser a função pedagógica da festa entendida como de transmissão cultural, de saberes e técnicas intergeracionais.

\section{AS IDENTIDADES TERRITORIAIS}

A festa além de educar seus membros para a participação no evento cria paisagens que os participantes do grupo de Congado associam como pertencentes à Festa do Rosário. Pudemos em nossas investigações notar objetos presentes na espacialidade do distrito que durante o período não festivo acabam por revelar e remeter ao Congado. Algumas casas visitadas durante a festa, buracos feitos no pátio da Igreja para realização do levantamento do mastro e velados apenas com pedras durante os momentos de missas comuns no ano, são ilustrativos do exposto. Assim, é criada uma identidade territorial a partir dos usos e apropriações dos lugares do distrito, expressos nos símbolos que nele se espacializam, o que atua também numa educação permanente dos sujeitos, pois não é somente durante a festa que ocorre a pedagogização. É como se houvesse uma ritualização permanente, tudo é constantemente celebrado, a disciplinarização espacial é diariamente efetuada. Os objetos que se estendem pelo espaço geram ações que reiteram significações, a dialética do espaço se confirma no movimento da vida, onde se expressam identidades territorializantes e territorializadas.

A forma de constituição do distrito também remete à construção de identidades territoriais. É nítida sua separação em duas partes: uma de existência mais antiga, conhecida como as terras de São José; e aquelas de povoamento mais recentes, por onde o distrito tem hoje se expandido. As terras do Santo, assim chamadas por serem terras doadas pela Igreja, cujo padroeiro no distrito é São José, são as terras onde a festa ocorre desde seu início. As terras dos fazendeiros são aquelas que só nas décadas recentes começaram a ser povoadas em função de loteamentos realizados por seus donos. A transcrição de fragmentos do diário relata a respeito:

Quando passamos próximo ao córrego, Seu Zeca chamou atenção para este ponto como demarcação do início das terras do Santo. Estas terras pertencentes à Igreja foram cedidas, através de um recibo, mas não de escritura, para que as pessoas construíssem. "Agora Dom Luciano autorizou que fossem dadas as escrituras das terras para quem já possui construções no local." "Dom Luciano foi muito bom pro povo". (Seu Zeca)

Seu Zeca retornou à questão da divisão de terras. Segundo ele, "no princípio o distrito não evoluía" em função dos terrenos pertencerem a fazendeiros, que não estavam dispostos nem a vender nem a doar terras, o que não permitia o crescimento do Fundão. Só com a venda de lotes pelos herdeiros dos fazendeiros é que o distrito começou a crescer.

Eles apontam que no passado todo o espaço, que por ora estávamos percorrendo, já foi um matagal e lavouras de café.

Questionei se apesar deles não terem sido os primeiros moradores daquele local eles estiveram presentes desde o início do adensamento de povoamento. Seu Zeca respondeu que desde o início o movimento deles era ali, que as vendas onde se fazia compra se localizavam ali, que o trajeto que se percorria para ir para o trabalho e para a cidade passava por ali, assim como as missas, as rezas e os estudos, "tudo era aqui". Seu Zeca conclui: "Eu não troco aqui por uma casa na cidade, porque eu gosto demais daqui." (Diário de Campo, 27/06/2007)

É o crescimento do distrito rumo às "terras dos fazendeiros" que faz com que o distrito se dinamize mais fortemente na atualidade em termos do crescimento de dinâmicas sociais. Como relatam os guardiões da memória, hoje, embora ainda quase todos os moradores se conheçam, muitas pessoas não se cumprimentam. Cresce também o número de pessoas de outras etnias e de outras formas de sociabilidade. Por diversas vezes é possível notar na fala dos guardiões da memória o reclame quanto à sensível perda de centralidade da Festa do Rosário como elemento socializador no distrito. O trecho do diário é elucidativo:

Ao andarmos por um espaço em que não diziam muito sobre o Congado, surgiu o assunto de um batizado. Seu Zeca começou então a falar das mudanças no Fundão. Segundo ele, se antigamente tinha um batizado ali, todo mundo se reunia nele, não havia mais nenhum outro evento no Fundão. "Batizado e casamento hoje tem todo dia, agora é diferente, várias coisas acontecem ao mesmo momento, é muita gente. Se se fazia um tutu era coisa diferente e todo mundo se reunia em volta daquilo, hoje isso tem em todo lugar, em todos os eventos. Missa, hoje tem no Fundão, na Cachoeirinha, no Buieié." João faz então observações em torno das mudanças das formas das casas no Fundão que, segundo ele, antigamente eram de sapê. 
"Êta ferro! Isto aqui tudo era roça rapaz!" (Diário de Campo, 27/06/2007)

Outro traço das identidades territoriais colocados em relevo pela festa, diz respeito às toponímias do distrito. Embora a maior parte das ruas do distrito sejam conhecidas pelos moradores em função da moradia de uma pessoa de grande poderio de sociabilidade ou de grande tempo de moradia naquela localidade, se reconhecer na nomenclatura oficial do distrito dá aos "guardiões" um sentimento de pertencimento e de domínio de determinados lugares. As falas abaixo, proferidas durante a Caminhada Transversal, técnica do Diagnóstico Rápido Participativo, expressa este aspecto:

"Essa aqui é a Rua Alaídia Bernadino, viu?!" Todos riram com a exclamação de João; é a rua com nome de sua mãe. AAlvorada passa pela rua.

Apontaram em seguida pra outra rua desenhada no mapa, a Antônio Lopes de Almeida, "que vai para um caminho da roça". Esta rua foi doação da mãe do antigo morador que dá nome a rua, que "é da família dos donos de todas estas terras aí para frente." (Diário de Campo, 27/06/2007)

\section{CONSIDERAÇÕES FINAIS}

Remontar às chamas do candeeiro para o desenvolvimento deste trabalho constituiu-se em construção de cena bastante interessante para apreensão das geografias da memória estabelecidas no espaço-tempo de São José do Triunfo. A imagem fez bom trânsito entre as memórias e as espacialidades que se transformaram pelos tempos experienciados pelos sujeitos da pesquisa.

O estudo nos revelou que embora seja a Festa do Rosário a grande cimentadora das sociabilidades que se estabelecem no distrito de São José do Triunfo e que dá significação às espacialidades daquele lugar, este evento não se estagnou no tempo. Embora haja esforços de cristalização de momentos vividos pelos sujeitos celebrantes do Congado em determinados objetos espaciais, a festa está naquele lugar em constante movimento no sentido espaço-temporal, moldando novas realidades e configurações espaciais e se adequando às mesmas. Se o lembrar dos festejos do Congado ainda em chão de terra e iluminados por candeeiros traz nostalgia aos celebrantes da festa, festejar sobre o asfalto e sob luz de poste não os faz menos fervorosos ou celebrantes em seus festejos. Como dito, o óleo e o querosene que agora alimentam a festa não são mais provenientes dos candeeiros, mas dos combustíveis da memória que alimentam as chamas das (temp) oralidades e das geo-grafias memoriais nos rituais do Congado.

Em meio a estas imagens, sons e movimentos, o estudo nos revelou consistentes inter-relações entre a Festa do Rosário e a configuração espaço-temporal de São José do Triunfo. A análise das relações de gênero e das questões étnicas - enquanto subjetividades - se fez possível pelas características dialógicas dos instrumentos metodológicos empregados, permitindo emergir nas territorialidades do Congado, o inter-jogo histórico das identidades. Tal metodologia possibilitou a formulação de uma série de materiais, tais como narrativas memoriais e confecção de mapas mentais, que permitiram o estabelecimento de aproximações entre a Festa de Nossa Senhora do Rosário e o lugar festivo do espaço analisado.

Os vínculos entre a Festa do Rosário e o distrito mostraram a força do evento festivo como constituidor de sociabilidades e agregador de memórias comuns que asseguram a história de um lugar. A oralidade e as corporeidades, como instrumentos transmissores de um saber e conjunto de ações, revelaram o poder da ancestralidade no processo de territorialização dos povos negros em espaços brasileiros. Pudemos perceber como na Irmandade de Negros de São José do Triunfo a negritude se constitui como elemento de mediação na constituição de uma dinâmica de vida que, embora com grande poder de mutação, consegue manter e rearranjar elementos de um passado comum e um presente conexo.

Ainda neste sentido, as relações étnico-raciais e de gênero mostraram como as espacialidades festivas do Congado de São José do Triunfo ao longo dos tempos se produziram a partir das hierarquizações formuladas nestas relações, confirmadas nas diversas materialidades dispostas nos acúmulos das paisagens daquele distrito e dinamizadas nas relações que historicamente estabeleceram o simbólico manifestado nos seus lugares. Homens e mulheres, negros e não negros, jovens e velhos, criaram, em suas vivências, tessituras que construíram uma memória capaz de fortalecer a história de um lugar que se constitui a partir das lembranças de vidas e de resistências, de lutas e conquistas, de duros cotidianos e de grandiosas festas.

A Festa do Rosário se revelou, pois, como um território encantado por vivências que textualiza a história dos povos negros na cidade de Viçosa, que, embora não encerre toda a multiplicidade de constituição de lugares destes povos nesta terra, muito diz sobre sua dinâmica. As escritas/inscrições espaciais identificadas, 
mais do que ressaltar sobre a configuração de um local, revelaram, pois, sobre a constituição de um lugar e a construção de um espaço.

Lugar, festa e memória, foram, dessa maneira, alicerces para que eu pudesse apreender como o distrito de São José do Triunfo se constitui em espaço matizado de histórias que, quando celebrado pelos festejos de Nossa Senhora do Rosário, se torna um

\section{REFERÊNCIAS}

BENJAMIN, W. O Narrador. In: LOPARIC, Z.; FIORI, O. B. (Org). Os Pensadores XLVIII: Textos Escolhidos. São Paulo: Abril Cultural, 1975. p. 63-81.

BRUNER, J. A interpretação narrativa da realidade. In: A cultura da educação. Porto Alegre: ARTMED, $\overline{2001 . p}$. 127-143.

CARLOS, A. F. A. O lugar no/do mundo. São Paulo: Hucitec, 1996.

FERREIRA, L. F. O lugar festivo: a festa como essência espaço-temporal do lugar. Espaço e Cultura, Rio de Janeiro, v. 15, p. 7-21, jan./jun. 2003.

GIACALONE, F. Festa e percursos da educação intercultural. In: FLEURI, R. M. (Org.). Intercultura e movimentos sociais. Florianópolis: Mover, NUP, 1998. p. 127-145.

HALBWACHS, M. A memória coletiva. São Paulo: Vértice, 1990.

HISSA, C. E. V. A mobilidade das fronteiras: inserções da geografia na crise da modernidade. Belo Horizonte: Ed. UFMG, 2002.

LAMAS, F. G; SARAIVA, L. F.; ALMICO, R. C. S. A Zona da Mata Mineira: Subsídios para uma historiografia. Disponível em: <http://www.abphe.org.br/congresso2003/Textos/ Abphe_2003_09.pdf>. Acesso em: 08/05/2008.

LINDÓN, A. De las geografias constructivistas a las narrativas de vida espaciales como metodologias geográficas cualitativas. Revista da Anpege, v.4, p. 03-27, 2008. lugar festivo, aquele em que a Irmandade de Negros do distrito escreve e inscreve suas histórias em espaços, e que permite que suas geografias perdurem no tempo; criando geo-grafias memoriais.

MARTINS, L. M. Afrografias da Memória: O Reinado do Rosário no Jatobá. São Paulo: Perspectiva; Belo Horizonte: Mazza Edições, 1997.

MARTINS, L. M. Performances do tempo espiralar. In: RAVETTI, G.; ARBEX, M. (Orgs.). Performance, exílio, fronteiras: errâncias territoriais e textuais. Belo Horizonte: Departamento de Letras Românicas, Faculdade de Letras/ UFMG: Poslit, 2002.

MARTINS, L. M. A oralitura da memória. In: FONSECA, M. N. S. (Org.). Brasil afro-brasileiro. Belo Horizonte: Autêntica, 2006. p. 61-86.

PANIAGO, M. C. T. Viçosa - Mudanças sociais e socioculturais; evolução histórica e tendências. Viçosa: Imprensa Universitária, 1990.

POLLAK, M. Memória e Identidade Social. Estudos Históricos, Rio de Janeiro, v. 5, n. 10, p. 200-212, 1992.

ROBERTO, A. de P. A Festa de Nossa Senhora do Rosário no Serro, Minas Gerais: a reinvenção de uma tradição. Dissertação (Mestrado em Extensão Rural) - Departamento de Economia Rural, Programa de Pós-Graduação em Extensão Rural, Universidade Federal de Viçosa, Viçosa 2000.

SANTOS, B. de S. A gramática do tempo: para uma nova cultura política. São Paulo: Cortez, 2006.

TUAN, Y. Espaço e lugar: a perspectiva da experiência. São Paulo: DIFEL, 1983.

VON SIMSOM, Olga Rodrigues de Moraes. Memória, cultura e poder na sociedade do esquecimento: o exemplo do Centro de Memória da Unicamp. Disponível em: <http://www.ufpa.br/ nupe/artigo1.htm>. Acesso em: 27/11/2008. 
